\title{
Tonal Poetry, Bop Aesthetics, and Jack Kerouac's Visions of Gerard
}

James J. Donahue

\section{(2) OpenEdition \\ Journals}

Electronic version

URL: https://journals.openedition.org/ejas/12711

DOI: 10.4000/ejas.12711

ISSN: 1991-9336

Publisher

European Association for American Studies

\section{Electronic reference}

James J. Donahue, "Tonal Poetry, Bop Aesthetics, and Jack Kerouac's Visions of Gerard", European journal of American studies [Online], 13-2 | 2018, Online since 29 June 2018, connection on 08 July 2021. URL: http://journals.openedition.org/ejas/12711 ; DOI: https://doi.org/10.4000/ejas.12711

This text was automatically generated on 8 July 2021 .

Creative Commons License 


\title{
Tonal Poetry, Bop Aesthetics, and Jack Kerouac's Visions of Gerard
}

\author{
James J. Donahue
}

11956 was a remarkable year for American jazz. The Modern Jazz Quartet ${ }^{1}$ released their album Django; Ella Fitzgerald released three albums, including Ella and Louis with Louis Armstrong; and Miles Davis released six-yes, six!-albums including the debut record of the new Miles Davis Quintet, his first recording with John Coltrane. And in the midst of the prolific output of some of the giants of jazz's bop era, Charles Mingus released his $10^{\text {th }}$ album, Pithecanthropus Erectus, the album that many critics consider to be Mingus's first great album as a composer and not just as a bandleader.

2 The literary scene in the United States was no less vibrant. In poetry, Gwendolyn Brooks released Bronzeville Boys and Girls, the fourth book documenting the lives of those living in the Bronzeville neighborhood of Chicago; John Ashbery released Some Trees, for which he won the Yale Younger Poets Prize; and Allen Ginsberg's Howl and Other Poems was published as the fourth volume of Lawrence Ferlinghetti's new Pocket Poets Series. And in fiction, James Baldwin published Giovanni's Room, his controversial novel exploring homosexuality; Saul Bellow published his influential novel Seize the Day; and Pearl S. Buck published Imperial Woman, her fictionalized biography of Tzu Hsi. Meanwhile, Jack Kerouac was composing his touching and personal novel about his brother, Visions of Gerard (which would not be published until 1963).

3 The Beat Movement's interest in jazz is, of course, already well-trodden ground. And Kerouac's jazz poetics has been explored by a number of scholars. To give just a few note-worthy examples, in his 1999 article "'Jazz America': Jazz and African American Culture in Jack Kerouac's On the Road," Douglas Malcolm reads Kerouac's most notorious novel "in light of the various generic rules that distinguish jazz from other types of music" in order to identify the music's "ideological, behavioral, and semiotic implications" for the novel (85). In the same year, James Campbell wrote about Kerouac's problematic use of African American culture and how "the black word beat turned white" (363) in his article "Kerouac's Blues." And in 2004, Richard Quinn published a book chapter comparing Jack Kerouac's improvisational method to Charlie 
Parker's, outlining Kerouac's “engaging with the openness of bebop and extending its improvisational practices into language" (153) while highlighting "the improvisation experience in reading Beat writing" (154).

4 Extending the work done to this point, and perhaps moving a step further in commenting upon the connection between jazz and the fiction the Beat movement, I believe that not as much attention has been explicitly paid to appreciating the aural components of Beat fiction, to reading Beat novels as bop soundscapes. What I hope to do with this article is show how Kerouac's novel is, in short, a jazz tone poem. But if this is merely a question of genre, so what? Just call it poetry and move on. However, this is not simply about classification, or about where to shelve Kerouac's novels in bookstores. Far too often prose, even literary prose, is not considered to be an aural art, not valued for its tonal qualities, not appreciated (except perhaps during a live reading, and then only obliquely) for its sonic components. Most fiction-even the fiction produced by authors like Kerouac, who are known not only for drawing compositional methods from music but also for having acutely sensitive ears for language-is primarily read as textual narrative. ${ }^{2}$ Kerouac's Visions of Gerard in particular-and, I would argue, much of Kerouac's fiction generally ${ }^{3}$-can and should be read as a musical composition; and reading it with an ear attuned to Mingus's great work helps us to highlight the novel's aural compositional qualities.

5 It's lucky for me, then, that Mingus's album was released in 1956, the year Kerouac composed Visions of Gerard, as this coincidence allows me to connect the two compositions, using the one to properly frame the other. I also focus on Pithecanthropus Erectus because Mingus himself, in the album's original liner notes, calls the piece "a jazz tone poem." Mingus refers to his composition as a work of literature, in part to emphasize its narrative development: "because it depicts musically [his] conception of the modern counterpart of the first man to stand erect." Similarly, he notes that " $[\mathrm{t}] \mathrm{he}$ first movements are played in ABAC form by the group," using notation that is also commonly used when teaching students about poetic rhyme schemes (Mingus, "Liner Notes"). Mingus clearly had literary artistry in mind both when he was composing this piece, and later when he was reflecting on it.

6 Just as importantly, Mingus consciously composed this piece on what he called "mental score paper," meaning that he did not write the parts down for his band but rather "la[id] out the compositions part by part to the musicians" (qtd. in Nicholson). In other words, Mingus did not present copies of the score to his band, but rather played them the parts, and asked them to learn the charts by ear. This relatively uncommon method allowed Mingus to "keep [his] own compositional flavor in the pieces and yet... allow the musicians more individual freedom in the creation of their group lines and solos" (Mingus). (We see a similar approach on The Modern Jazz Quartet's Django; "La Ronde Suite"-a version of Dizzy Gillespie's "Two Bass Hit"-was arranged to highlight specific contributions from the individual musicians.) Even though it is common for jazz musicians to interpret the written score individually-especially at this moment, as performers are already experimenting with what we might call the performative freedoms that will later characterize free jazz-the written score generally provides a common text that holds the composition together, and to which each musician is held. Such a master text does not exist for this album, or rather did not at the time; one can go out and purchase the charts for Pithecanthropus Erectus, which are a transcription of the music that was recorded on the album. 
7 Mingus himself admits that he has "often been accused of being 'way out' compositionally" (Mingus), which is also a fair-if overly general-way of characterizing Beat writing, and Kerouac's writing especially, given the various compositions and thematic experimentations he attempted over the course of his career in works like Dr. Sax, Desolation Angels, Visions of Cody, and much of his poetry. And Kerouac's indebtedness to jazz for his compositional philosophy is well known. In "Belief \& Technique for Modern Prose," the $7^{\text {th }}$ item on his "List of Essentials" is "Blow as deep as you want to blow" (483). Although this can be taken in a variety of ways, certainly one of them is as an invitation to use the work to develop one's own artistic needs, not unlike how Mingus's band mates use the song as a platform from which to explore their own contributions to the overall soundscape. Kerouac made a similar statement in "Essentials of Spontaneous Prose," where he suggested that the art of writing is "sketching language [as] undisturbed flow from the mind," which he likened to "blowing (as per jazz musician)" (484), who should "blow!-now! Your way is your only way" (485).

8 Nor was Kerouac the only Beat writer who drew from jazz as a compositional as well as a thematic model, or concerned with the aural component of literary composition. In "Notes Written on Finally Recording Howl" (written in 1959) Allen Ginsberg remarks on "the whole first section typed out madly in one afternoon" that he had in mind "long saxophone-like chorus lines I knew Kerouac would hear the sound of-taking off from his own inspired prose line really a new poetry" (229). Ginsberg also noted, in his essay "Some Metamorphoses of Personal Prosody" (written in 1966), the importance of developing a "new ear," which is "not dead because it's not only for eye-page, it's connected with a voice improvising, with hesitancies aloud, a living musician's ear" (259, emphasis added). And of course, Ginsberg's emphasis on breathing in his own performances (either in terms of when he draws his breath or how he constructs what has often been called his "breath line") can be understood in terms familiar to singers (not to mention brass and woodwind players). In short, many aspects of Beat literary composition-not just for poetry but also for prose-can be understood as directly drawn from the compositional and performative models of jazz in the 1950s and 1960s, and focused on the aural components of literary practice.

Kerouac's aural composition can likely best be appreciated by listening to his poetry, particularly when he read it with musical accompaniment. Kerouac's recordings with Steve Allen-or better yet, those with Al Cohn and Zoot Sims-clearly demonstrate the call-and-response techniques that are familiar to jazz audiences. The Jack Kerouac Collection-a 3 CD set released in 1990-includes two CDs with readings most likely recorded in 1958, featuring Kerouac reading with musical accompaniment. On "Poetry for the Beat Generation," Kerouac reads poetry over Steve Allen's piano. And on "Blues and Haikus," he reads his haiku in a call-and-response format against Al Cohn and Zoot Sims taking turns improvising saxophone replies to the poetry. In the latter recording, one can clearly hear all three performers playing off of each other, as Kerouac will shift the tone of his voice to approximate what he hears from the saxophones, and the musicians play short lines that often mimic Kerouac's vocal rhythms. And in his essay accompanying the music, Lowell Sun correspondent David Perry noted that this recording is "the more musical" of the two, even while "it maintains the one-take feel of the first with chuckles, the rustle of papers and even someone calling out a chord change" (5). In other words, we have here a version of Kerouac "la[ying] out the 
compositions part by part to the musicians," who are replying to Kerouac based on what they hear, as opposed to anything written down.

of course, an aural appreciation of Kerouac's work isn't necessarily new. In her recent biography The Voice is All, Joyce Johnson tells us about Kerouac that "nothing gave him more pleasure, as he wrote to Neal Cassady... than writing down everything that occurred to him "with all sorts of silly little remarks and noises"' (249). We see plenty of examples of this in his poetry. For example, as Michael McClure reminds us, portions of the 1959 poem Old Angel Midnight are little more than transcriptions of what was happening outside his window, such as the excerpt that "was written while millions of birds were 'yakking' and 'barking"' [xv].) Similarly, Johnson writes of Kerouac's "new poetic approach to language" (336) in her discussion of On the Road, focusing explicitly on "the deliberate alliterative repetitions of the melancholy sound of the long 0 " (335) in the passage recounting Red Moultrie's night in jail, and especially in the passage where he "listened to the silence," aurally connecting a "sea-roar" to the word "rumorous," for instance (336).

11 And while Johnson does a good job of noting Kerouac's appreciation of sound in his fiction, I think that with respect to Kerouac's writing, there is a deliberate effort not only at aural appreciation, but aural composition. And while this has become a commonplace observation regarding his poetry, I argue that we should consider it as foundational in the composition of his prose, as well. Such an approach may well be indebted to-or at the very least works parallel to-the compositional practices of jazz musicians of the period. For instance, we know that Kerouac and his circle were enthusiastic fans of Thelonious Monk's music, which has often been hailed by critics for its improvisational strengths. In a 1953 letter to Allen Ginsberg and William Burroughs, Kerouac includes Monk in the list of "musical geniuses" alongside "Bud Powell, Bird, Billy Holiday, Lester Young, [and] Jerry Mulligan" (Letters 197). In a 1957 letter to John Clellon Holmes, Kerouac notes having just attended one of Monk's performances with Gilbert Millstein (Selected Letters 91). And in 1958, Ginsberg wrote to Kerouac of the pleasure of "hours of anonymous Thelonious Monk" (403). It cannot be too far a stretch, then, to connect the Beat writers to other improvisational and experimental jazz performers and composers of the period. And in particular, I believe that we have compelling comparative evidence to suggest that Jack Kerouac was listening to-and perhaps even inspired by-the music of Charles Mingus, who was consciously developing his unique compositional methods during the 1950s, and which are featured on the album Pithecanthropus Erectus. The album is important in this context both as a "jazz tone poem" and as an expression of Mingus's aurally-based style of band leading. And given Kerouac's conscious focus during this time on poetry as an exploration of sound as opposed to a repository for meaning, I think we would do well to attend to the overall soundscape of his novel Visions of Gerard, which was written during this period of aural exploration highlighted by numerous jazz performers noted from their improvisational technique.

12 To begin, Visions of Gerard may be Kerouac's most French novel, regularly incorporating snippets of the joual ${ }^{5}$ that the Kerouac family spoke in the home. In her biography, Johnson spends much time writing about Kerouac's French-Canadian background and its affect on his writing. And referring to the sensitive ear that earned Kerouac the nickname Memory Babe, Johnson also notes that he "had been born with an incredible ear," and that at the age of four, "Jack caught the doleful underlying sound of their 
lamentations" (37). In other words, from his earliest years, Kerouac was clearly-if not exactly consciously-sensitive to his aural environment, which he would attempt to mimic first in his speech and later in his prose. And there are moments where Kerouac shares that environment with his reader, such as when he explains to his reader how to pronounce the French words he uses: "Passes were the name Gerard had invented for when you run your bread over gravy, and mother'd do the soaking and throw the passes all around the table.... But because of our semi-Iroquoian French-Canadian accent passe was pronounced PAUSS so I can still hear the lugubrious sound of it and comfort-asuppers of it, M'uén pauss" (14). But Kerouac is doing more here than simply explaining to readers how to pronounce the words. He is also sharing with his audience the sadness associated with even his pleasant memories of Gerard; for while these moments contain "comfort-a-suppers" and recall moments when his family were still together, the very sound is also "lugubrious," a wonderfully onomatopoetic word connoting sustained sadness in its multiple long, low vowel sounds.

In a similar vein, Kerouac writes of the young boy "Plourdes," who possesses "[a] Canadian name containing in it for me all the despair, raw gricky hopelessness, cold and chapped sorrow of Lowell-Like the abandoned howl of a dog and no one to open the door" (5). This name ${ }^{6}-$ the similarly lugubrious sound of the name, and not its etymology or the family that bears it-conjures up a great deal of meaning for Kerouac, recalling not just the person but the emotions associated with his time in Lowell. And to help invoke this environment for his readers-particularly those who are hearing the sounds of the words-he employs a word that, because it does not have a dictionary definition, only carries meaning based on its sound. I can't define "gricky," but I suspect that Kerouac heard in it something similar to what Dr. Seuss-another author who valued the aurality of his written compositions-likely heard in the "grickle grass" that grows at the far end of town in the world of The Lorax, where the "wind smells slow and sour when it blows" (The Lorax); the short vowel sound paired with the unvoiced consonant cluster of "ick" helps to evoke what makes Lowell, for Kerouac, undesirable. We see many such moments in Kerouac's novel, such as his use of "glooping" (Gerard 111) to describe a dream he had, a gloomy dream where he was snooping around Gerard's coffin.

All that said, I believe we should also spend more time reading Kerouac's prose for the various ways it creates sonic developments and progressions to create meaning, to move the action forward, or to enhance the emotional depth of a scene. In other words, we should devote more time and attention to reading Kerouac's fiction-and perhaps Beat fiction more generally-as tonal poetry that performs a kind of bop aesthetics. For instance, there are numerous instances throughout Visions of Gerard where Kerouac concatenates phrases in ways that resemble musicians repeating riffs. These phrases are often repetitions of the same idea. However, when read aloud, these passages also reflect a rhythmic as well as a semantic connection, using the musicality of the phrases as a form of emphasis. Early on in the novel, Kerouac compares Gerard to those who do not have his sweet sensibility, when Gerard feels empathy for a mouse caught in a trap and the other "Canucks of Lowell" scoff at his concern. Kerouac writes, "I dont [sic] count Gerard in that seedy lot, that crew of bulls" ( 9 , emphasis mine). The italicized phrases, both serving to negatively characterize the men, are rhythmically identical, with a spondee (two stressed syllables) followed by an iamb (an unstressed syllable followed by a stressed syllable). ${ }^{7}$ The musicality of these phrases-referring to the men but in a way designed to highlight Gerard-is heard when read against the 
comparatively unstructured rhythm of their characterization as "Pot-boys, bonecarriers, funeral directors, glove-wearers, fog-breathers, shit-betiders, pissers, befoulers, stenchers, fat calf converters, utter blots \& scabs on the face of the earth" (9). This passage is a list, and structured without any coherent rhythmic patterning, as opposed to the earlier passage which is a conscious repetition, rhythmically as well as semantically.

We see another example of rhythmic repetition even earlier in the novel, which should be noted because Kerouac translates a passage from the joual he spoke as a child into the English he writes in as an adult, and does so while keeping the same number of words with the same syllabic pattern. He translates his father's "Mon pauvre ti Loup" as "me poor lil wolf." 8 Often, Kerouac will translate the joual for his readers, many of whom will not be familiar with the language he grew up with, and which he eschews for most of his writing. However, that language is what was spoken in the home, and so its use helps to set the scene of his childhood. Kerouac is here not merely describing his childhood but aurally representing it for his audience. Further, the ungrammatical "me poor lil wolf" reflects his father's comparatively poor skills with English. ${ }^{9}$ As such, the translation helps to flesh out the character of "Emil Duluoz." In my reading, the use of "me" for "my," and the shortening of "little" to "lil" serve an additional purpose; while drawing attention to Emil's English, they also de-emphasize the syllabic stress carried by those words. In my reading, "me" is unstressed, where "my" would be stressed in order to emphasize possession; similarly, "little" is a trochee, where "lil" can serve as the unstressed part of an iambic foot with "wolf." Therefore, this passage contains a musical quality: each phrase can be read as iambic tetrameter, and so the translation can be read as a means of preserving not just the meaning of the first phrase but the speech pattern of the speaker. In this regard, we can read a speaker moving from one language to another as not unlike a musician moving from one key to another, while preserving the rhythm of the passage in addition to the melody. (If we were so inclined, we could read Emil's whole quoted passage musically: "Mon pauvre ti Loup, me poor lil wolf, you were born to suffer" employs a pair of phrases in iambic tetrameter, followed by a line in trochaic hexameter, which reverses the syllabic stress. We can thus read the break after the repeated phrases as a kind of chiasmus, altering the rhythm of the sentence while maintaining the same emotional quality. This is not unlike musical instruments playing polyrhythmically in the same measure.)

Kerouac will also often go on short runs where he strings words together connected by their sounds as well as their semantic value. For instance, he described the Virgin Mary -particularly as she speaks through Gerard-as "Beauteous beyond bounds and belief" (52), employing alliteration to emphasize the value of this description, particularly to the very devout Gerard. Throughout the novel, Kerouac will employ short, alliterative riffs that appear to demonstrate a conversational patter as much as they describe the subject at hand, such as his father, who was a "proficient persuader" (86), so described using a pair of three-syllable alliterating words; his father will later be described by a friend as a "perfect person" (101), using the same alliterative sounds (albeit with a different rhythmic pattern). Of course, readers of his poetry will be familiar with such riffs, such as in the various choruses of Mexico City Blues (written in 1955, one year before Visions of Gerard ${ }^{10}$ ) where Kerouac engages in sound-based wordplay, even if he slips into the nonsensical, as in the " $82^{\text {nd }}$ Chorus" when he writes of "Fracons, acons, \& beggs" (82) or in the "94 $4^{\text {th }}$ Chorus" where he describes his time spent "talkin and gossipin / lockin and rossipin" (94). However, unlike these and other examples from his 
verse, the use of alliteration in his fiction serves a semantic purpose beyond mere wordplay. The above examples all serve to highlight the importance of the subjects, who themselves are important figures in Gerard's life: the holy mother he prayed to, the loving father who tended to him. And once noted, the reader will surely discover other examples throughout the novel, particularly in those long, run-on sentences that Kerouac surely composed aurally.

I would like to suggest that the various aurally-based compositional moments scattered throughout the novel serve to set the reader up for the narrative's climactic moment, when Kerouac finally comes to accept the death of his brother. Because Gerard's death was noted in the novel's opening sentence, even those readers unfamiliar with Kerouac's biography learn immediately about Gerard's fate. Rather, the novel's climax comes when Kerouac himself openly addresses the various conflicting emotions that this memory raises for him, and which he has been sharing with his readers in such moments as those noted above. In other words, Kerouac has been slowly introducing these various moments, not unlike the way a bandleader would have his fellow musicians come in one at a time, each adding a different piece of the overall soundscape before moving on to the musical climax.

Thus, arguably the most significant musical passage of Visions of Gerard comes near the end of the novel, when Kerouac is attempting to come to terms with his brother's death. While clearly traumatized by this event (remember that Jack was only four at the time of Gerard's death), Kerouac is just as clearly also trying to remember and record the beauty that he (and others) saw in his brother. These conflicting emotionslove for his brother but grief for his passing-as well as his conflicting impulses-to sing his brother's praises while lamenting his death-can be heard in the musicality of his comments on the funeral, particularly at the end of the seemingly meandering 2-page sentence building up to his acceptance of Gerard's death:

of emptiness, of pure light, of imagination, of mind, mind-only, madness, mental woe, the strivings of mind pain, the working at thinking which is all this imagined death \& false life, phantasmal beings, phantoms finagling in the gloom, goopy poor figures haranguing and failing with lack-hands in a fallen-angel world of shadows and glore, the central entire essence of which is dazzling radiant blissful ecstasy unending, the unbelievable Truth that cracks open in my head like an oyster and I see it, the house disappears in her Swarm of Snow, Gerard is dead and the soul is dead and the world is dead and dead is dead (111).

To begin, this is the longest of the many run-on sentences in the novel, and should be read not just as a "solo piece," but also in light of the run-on sentence Allen Ginsberg employed in the first section of his 1955 poem "Howl," given that both are painful laments uttered by distraught speakers. This sentence demonstrates Kerouac's inability to rein himself in, or give syntactic form to the emotions he needs to express. But that does not mean that this passage is "formless," or without an organizing principle. When heard rather than merely read, the formal qualities based on sound can be better appreciated.

We can hear in this short passage the way that Kerouac uses the continuous (and, as such, a kind of "run-on") bilabial nasal consonant " $m$ " to connect a host of ideas and images, and does so by moving through the successive stages of alliteration, internal rhyme, and end rhyme, drawing the reader through mind, madness, and mental woe to the imagined and the phantasmal, bringing this musical line to a close with the phantoms and the gloom. The reader is here then taken through Kerouac's own inner 
development, beginning with his mind and his mental anguish (presumably, the pain that comes from thinking about these events), moving through that which he imagines (perhaps the book he is writing and the characters he is creating, who may be read as phantom versions of his family?), and ending on the general mood, felt by him but also shared by all present at the funeral (and likely the novel's audience as well). As such, Kerouac is subtly but decisively using alliteration to suggest a narratological development, moving from the author, through the characters, and finally to the readers. Then at the end of this aural connection, we hear that gloom is connected through strict alliteration to the goopy and the glore, two words that may at first blush appear to be nonsensical, but are granted meaning through the poetic effect of alliteration (as well as any lingering rhyme-based aural connections the readers may make, performing the same work that Dr. Suess's reader performs in understanding the role of "grickle grass" as well as possibly connecting back to the other "lugubrious" tones employed throughout the novel). In other words, Kerouac is creating meaning for these words based on a consciously aural method of composition.

Kerouac also uses alliteration in the "Swarm of Snow"-which he capitalizes in the text, perhaps to draw visual attention to his aural play-to move from the voiceless, sibilant, fricative sound of the s to the voiced alveolar stop of the $d$ in a consonantal progression from "Swarm of Snow" to "soul is dead" to "dead is dead." One could certainly read this move from the voiceless to the voiced, paired with the move from the sibilant to the alveolar, as an aural representation of Kerouac's own emotional turmoil. Pairing the voiced with the voiceless here suggests the paradox of Gerard's death along with his continued life in Kerouac's fiction. We may see a narrative version of this in the time Kerouac gave to Gerard's own voice, quoting him directly throughout the novel (and certainly more so than any of the other characters in the book), knowing that he cannot speak any more. The novel is both a representation of his voice as well as a reminder of its absence. Further, the continuation of a sibilant sound paired with the stop of the alveolar sound could thus suggest a conscious use of consonantal sound qualities to further address the paradox of Gerard's simultaneous presence and absence, a living on after his death. Here, perhaps, Kerouac is composing a poetic chiasmus to aurally reflect his emotional state.

And finally, we can hear in the final repetition a rhythmic pattern that alludes to what may be the most painful aspect of this funeral. The phrase "Gerard is dead" has four syllables (employing iambic tetrameter yet again), a rhythm repeated in "the soul is dead" and "the world is dead," before coming to the shortened "dead is dead." After three four-syllable phrases, this final phrase will no doubt sound shortened, removing the first unstressed syllable ${ }^{11}$ in what may sound like a quickening of the pace. Syllabically, we come to a very quick end, mimicking the painful loss of a life cut too short. And while I highly doubt that this was on Kerouac's mind as he composed the line, his use of a cretic metrical foot (two stressed syllables on either side of an unstressed syllable) was employed by classical Greek poets in paeans, or songs of praise. Certainly, the mood of the novel-and this passage in particular-is one of devastation; that said, this novel is also a celebration of Gerard's life and his continued impact on Kerouac into his adulthood. There may be no joy in this moment, but there is much about Gerard to celebrate, as I have addressed elsewhere. ${ }^{12}$

Obviously, space does not permit more than a cursory reading of this one novel, albeit a novel composed during a period that witnessed exciting aural advancements in both 
literary and musical composition. By reading the bop prosody of Jack Kerouac's prose in terms the compositional methods of Charles Mingus' tonal poetry, I hope to have hinted toward a richer, more nuanced reading of Kerouac's novel, if not Beat fiction more generally, while also alluding to perhaps a better understanding of the sonic landscape of the avant-garde art of mid-century America. And just as obviously, I am not suggesting that the entirety of Visions of Gerard can be read as a "tonal poem," that aesthetically rewards the reader at all points with the continuous musicality of the prose, unlike Pithecanthropus Erectus which does so reward its audience (although the novel certainly is aesthetically rewarding throughout due to other factors). Rather, Kerouac employs a more musical prose at various points for emphasis, as well as a reward for those readers who approach his prose with the same appreciation for jazz that he brought to its writing.

\section{BIBLIOGRAPHY}

Campbell, James. “Kerouac's Blues.” Antioch Review 57.3 (Summer 1999): 363-370. Print.

Donahue, James J. “Visions of Gerard and Jack Kerouac's Complicated Hagiography.” The Midwest Quarterly 51.1 (Autumn 2009): 26-44. Print.

Dr. Seuss. The Lorax. New York: Random House, 1971. Print.

Ginsberg, Allen. Deliberate Prose: Selected Essays 1952-1995. Foreword by Edward Sanders. Ed. Bill Morgan. New York: Perennial, 2001. Print.

---. “Notes Written on Finally Recording Howl." Deliberate Prose: Selected Essays 1952-1995. Foreword by Edward Sanders. Ed. Bill Morgan. New York: Perennial, 2001. 229-232. Print.

---. "Some Metamorphoses of Personal Prosody." Deliberate Prose: Selected Essays 1952-1995. Foreword by Edward Sanders. Ed. Bill Morgan. New York: Perennial, 2001. 258-260. Print.

Johnson, Joyce. The Voice is All: The Lonely Victory of Jack Kerouac. New York: Viking, 2012. Print.

Kerouac, Jack. "Belief \& Technique in Modern Prose.” The Portable Jack Kerouac. Ed. Ann Charters. New York: Viking, 1995. 483-484. Print.

---. "Blues and Haikus.” The Jack Kerouac Collection. Disc 2. Liner notes by Gilbert Millstein. 1990.

---. Desolation Angels. New York: Riverhead Books, 1965. Print.

---. "Essentials of Spontaneous Prose." The Portable Jack Kerouac. Ed. Ann Charters. New York:

Viking, 1995. 484-485. Print.

---. Mexico City Blues. New York: Grove Press, 1959. Print.

---. Old Angel Midnight. 1959. Prefaces by Ann Charters and Michael McClure. Ed. Donald Allen. San Francisco: Grey Fox Press, 1993. Print.

---. Selected Letters: 1957-1969. Ed. Ann Charters. New York: Penguin Books, 2000. Print.

---. Visions of Gerard. 1963. New York: Penguin Books, 1991. Print. 
Kerouac, Jack, and Allen Ginsberg. Jack Kerouac and Allen Ginsberg: The Letters. Ed. Bill Morgan and David Stanford. New York: Penguin, 2010. Print.

Malcolm, Douglas. “'Jazz America': Jazz and African American Culture in Jack Kerouac's On the Road." Contemporary Literature 40.1 (Spring 1999): 85-110. Print.

Mingus, Charles. Pithecanthropus Erectus. Atlantic Recording Corp. 1956. Original Liner Notes. (Atlantic Masters Reissue, liner notes by Stuart Nicholson.)

Perry, David. Introduction to The Jack Kerouac Collection: 3 CD Set. Burbank, CA: Rhino Records, 1990. 2-7.

Quinn, Richard. “Jack Kerouac, Charlie Parker, and the Poetics of Beat Improvisation." Reconstructing the Beats. Ed. Jennie Skerl. New York: Palgrave Macmillan, 2004. 151-167. Print.

\section{NOTES}

1. Proper Names: Modern Jazz Quartet, Ella Fitzgerald, Louis Armstrong, Miles Davis, Miles Davis Quintet, John Coltrane, Charles Mingus, Gwendolyn Brooks, John Ashbury, Allen Ginsberg, Lawrence Ferlinghetti, James Baldwin, Saul Bellow, Pearl S. Buck, Tzu Hsi, Jack Kerouac, Douglas Malcolm, James Campbell, Richard Quinn, Charlie Parker, Dizzy Gillespie, Steve Allen, Al Cohn, Zoot Sims, David Perry, Joyce Johnson, Neal Cassady, Michael Mcclure, Red Moultrie, William Burroughs, Bud Powell, Billy Holiday, Lester Young, Jerry Mulligan, John Clellon Holmes, Gilbert Millstein, Plourdes, Dr. Seuss, Emil Duluoz, Virgin Mary.

2. Although pedagogy is not my primary focus with this article, what follows can certainly be developed into a means to teach Beat fiction. In my own teaching, I find that students are more comfortable reading poetry out loud than they are reading prose out loud, both in the classroom and when doing their reading at home. Helping students to hear the aural components of fiction could very well encourage them to read fiction aloud more often. In particular, I know that I am not alone in insisting that Kerouac's novels demand to be heard as well as read.

3. Of course, some of Kerouac's prose will resist such a reading. For instance, chapter 37 of Desolation Angels contains material that cannot be read aloud. However, those passages are few and far between in Kerouac's prose, and can productively be considered as foils highlighting those passages that do operate as aural artistry. Much of the "Desolation in Solitude" section, in fact, is composed of language that is drawn from the radio conversations Kerouac was having while atop Desolation, and could productively be read according to the methodology I use in my reading of Visions of Gerard, particularly his various descriptions of "Hozomeen, Hozomeen, most beautiful mountain I ever seen" (4).

4. Given the complicated relationship Kerouac had with race, especially with African American culture (as James Campbell and others have addressed), I should note here that Mingus's title certainly has racial overtones, as pithecanthropus erectus has often been translated as "upright ape-man." Given the long history of referring to African Americans as apes, Mingus surely intended the racial overtones to ring out as clearly as the reference to the upright bass that he played. This multi-layered signification is not uncommon in jazz, and may well have been part of the Beat writers' interest in jazz culture. Respecting the multiplicity of interpretive possibilities is at the heart of jazz improvisation, as well as literary interpretation.

5. Joual is a sociolect of Québécois commonly associated with working class populations, and is characterized by the incorporation of loan words and phrases from English.

6. Many of the names Kerouac uses employ long, low vowel sounds: "Fournier" (35), "Bolduc" (63), and "Caribou" (73) being just a few of them. 
7. I should note, however, that reading for stress - especially in prose - can be subjective. One could just as easily read these phrases as iambic tetrameter (though I feel that Kerouac is placing emphasis on "that," to mark the group to which Gerard is being compared. Either way, there is a distinct rhythm and meter to these phrases.

8. Although the whole passage is presented as a direct quotation, Kerouac's readers know not to assume that quoted material is an accurate reflection of what was spoken. As biographical as his fiction is, it should not be read as unfiltered history, particularly in scenes from his childhood. In fact, we have every reason to believe that the artistry displayed in passages such as this one belong to Kerouac, and reflect the bop aesthetics of his approach to language.

9. Although Leo Kerouac had, as Joyce Johnson reminds us, "learned English well enough to be taken on as a printer's apprentice at the Telegraph, Nashua's English-speaking newspaper," he was much more comfortable with French, eventually working for the French-language papers L'Impartial and L'Etoile, the latter of which brought him to Lowell (32).

10. Given the proximity of their composition, it should come as no surprise that Gerard, and Kerouac's childhood more generally, are treated in a number of the choruses. And of course, the "choruses" themselves are meant to evoke the musical influences he was drawing from at the time.

11. I am not including the concatenating "and" as part of these phrases.

12. See my article "Visions of Gerard and Jack Kerouac's Complicated Hagiography," The Midwest Quarterly 51.1 (Autumn 2009): 26-44.

\section{ABSTRACTS}

In the following article, I will attempt to outline a new reading methodology for Beat fiction, based on some of the principles of bop aesthetics. This reading understands fiction-especially Beat fiction-as an aural art, as opposed to merely a textual phenomenon (and so considers fiction in much the same way that poetry and music are often considered). Jack Kerouac composed his novel Visions of Gerard in 1956 (released in 1963), the same year Charles Mingus released his classic album Pithecanthropus Erectus. I contend that by reading Kerouac's novel in terms of Mingus's methods of composition as recorded on that album, we can more clearly hear the influence of jazz music on Kerouac's prose; as such, we can better understand the means by which jazz music became important as a compositional method and not just as a theme for Kerouac's novels. Further, becoming more attuned to the means by which Kerouac composed his fiction as an aural soundscape-how he was sensitive not just to the words themselves but to the sounds that comprise those words and their relationships-we can better appreciate the various ways that Kerouac imbued his novels with aural qualities that emphasized the ideas and emotions raised and/or engaged by the narratives. 


\section{INDEX}

Keywords: jazz, Django, Ella and Louis, Pithecanthropus Erectus, Bronzeville Boys and Girls, Some Trees, Howl and Other Poems, Giovanni's Room, Seize the Day, Imperial Woman, Visions of Gerard, Beat Movement, jazz poetics, bebop, bop soundscape, jazz tone poem, free jazz, Dr. Sax, Desolation Angels, Visions of Cody," "Essentials of Spontaneous Prose," "Notes Written on Finally Composing Howl," "Some Metamorphoses of Personal Prosody," The Jack Kerouac Collection, Lowell Sun, The Voice is All, Old Angel Midnight, On the Road, joual, Memory Babe, Gerard Kerouac, Lowell, The Lorax, spondee, iamb, trochee, Mexico City Blues, bop prosody.

\section{AUTHOR}

\section{JAMES J. DONAHUE}

James J. Donahue is Associate Professor and Director of the graduate program in English \& Communication at The State University of New York, College at Potsdam. He is the author of two books: Failed Frontiersmen: White Men and Myth in the Post-Sixties American Historical Romance (University of Virginia Press, 2015) and Contemporary Native Fiction: Toward a Narrative Poetics of Survivance (Routledge, under contract); with Jennifer Ann Ho and Shaun Morgan, he is the editor of Narrative, Race, and Ethnicity in the United States (Ohio State University Press, 2017), and with Derek Maus he is the editor of Post-Soul Satire: Black Identity after Civil Rights (University of Mississippi Press, 2014). In addition to the European Journal of American Studies, his articles on American literature and culture have appeared in such journals as: JNT: Journal of Narrative Theory, The Midwest Quarterly, and SAIL: Studies in American Indian Literatures. 